\title{
Changes in essential oil and morpho-physiological traits of tarragon (Artemisia dracuncalus L.) in responses to arbuscular mycorrhizal fungus, AMF (Glomus intraradices N.C. Schenck \& G.S. Sm.) inoculation under salinity
}

\author{
Amin LAMIAN $^{1}$, Hassanali NAGHDI BADI ${ }^{2}$, Ali MEHRAFARIN ${ }^{2 *}$, Mehdi SEIF SAHANDI ${ }^{2}$
}

Received June 05, 2016; accepted July 06, 2017.

Delo je prispelo 05. junija 2016, sprejeto 06. julija 2017.

\begin{abstract}
This study aimed to evaluate the arbuscular mycorrhizal fungi (AMF) (Glomus intraradices N.C. Schenck \& G.S. Sm.) inoculation and salinity effect on qualitative and quantitative changes in tarragon yield. Treatments included inoculation, and non-inoculation of AMF, and five salinity levels of irrigation water (with the electrical conductivity of $0,2,4,6$, and $8 \mathrm{dS} \mathrm{m}^{-1}$ ). The results showed the plant height, SPAD value, number of leaves, dry mass of leaves and shoot per plant were reduced under salinity condition. The various levels of salinity decreased the content of tarragon essential oil and some its components consist of $\alpha$-pinene, limonene, $Z$ ocimene, E-ocimene, and methyl chavicol while, it increased the content of bornyl acetate, eugenol, methyl eugenol, caryophyllene, germacrene, and $\alpha$-farnesene. AMF inoculation without salinity had the greatest positive effect on the evaluated traits of tarragon. Also, it improved the morphophysiological traits under salinity due to alleviation of the harmful effects of salinity. Although the essential oil content was reduced with the AMF inoculation, the methyl chavicol amount was increased by the AMF inoculation under salinity condition.
\end{abstract}

Key words: arbuscular mycorrhizal fungi; Artemisia dracunculus L.; electrical conductivity; essential oils; Glomus intraradices; methyl chavicol; morpho-physiological traits; salinity

\section{IZVLEČEK}

\author{
SPREMEMBE V VSEBNOSTI ETERIČNIH OLJ IN \\ MORFOLOŠKO-FIZIOLOŠKIH LASTNOSTI \\ PEHTRANA (Artemisia dracuncalus L.) KOT ODZIV NA \\ INOKULACIJO Z ARBUSKULARNO MIKORIZNO \\ GLIVO (Glomus intraradices N.C. Schenck \& G.S. Sm.) V \\ RAZMERAH SLANOSTI
}

Namen te raziskave je bil oceniti vpliv inokulacije $\mathrm{z}$ arbuskularno mikorizno glivo (Glomus intraradices N.C. Schenck \& G.S. Sm.) in učinek slanosti na spremembe v kakovosti in količini pridelka pehtrana. Obravnavanja so obsegala inokulacijo in brez inokulacije z AMG ter pet stopenj slanosti vode za namakanje (z električno prevodnostjo $0,2,4$, 6 , in $8 \mathrm{dS} \mathrm{m}^{-1}$ ). Rezultati so pokazali, da so se vrednosti znakov kot so višina rastlin, SPAD vrednost, število listov, suha masa listov in število poganjkov na rastlino zmajšale $\mathrm{v}$ razmerah slanosti. Različne slanosti so zmanjšale vsebnosti eteričnih olj , med njimi $\alpha$-pinena, limonena, $Z$-ocimena, $E$ ocimena in metil kavikola medtem, ko so se vsebnosti bornil acetata, eugenola, metil eugenola, kariofilena, germakrena in $\alpha$-farnezena povečale. Inokulacija z AMG v razmerah brez slanosti je imela največje pozitivne učinke na vse ovrednotene lastnosti pehtrana. Izboljšala je tudi morfološke in fiziološke lastnosti v razmerah slanosti. Čeprav je bila vsebnost steričnih olj zmanjšana ob inokulaciji z AMG, se je vsebnost metil kavikola povečala $\mathrm{v}$ razmerah slanosti.

Ključne besede: arbuskularne mikorizne glive; Artemisia dracunculus L.; električna prevodnost; eterična olja; Glomus intraradices; metil kavikol; morfološko-fiziološke lastnosti; slanost

\footnotetext{
1 Department of Horticulture Science, Science and Research Branch, Islamic Azad University (IAU), Tehran, Iran

2 Medicinal Plants Research Center, Institute of Medicinal Plants, ACECR, Karaj, Iran; *Corresponding author: A.Mehrafarin@gmail.com
} 


\section{INTRODUCTION}

Tarragon (Artemisia dracunculus L.) is an herbaceous, perennial plant with alternate leaves of linear shape and light green color (Fernandez-Lizarazo et al., 2011). It is native to Russia and Siberia, alluvial valley areas, but today is spread also in the western areas of North America. However, tarragon is widespread also in parts of temperate Asia, as well as Central Asia and Eastern Europe (Fernandez-Lizarazo et al., 2011; Obolskiy et al., 2011). The tarragon leaves contain about $0.3 \%$ essential oil of which methyl chavicol comprise approximately $70 \%$ of its component. (Chopra et al., 1986; Verma et al., 2010). This plant possesses a wide range of health benefits, therefore, it widely used in traditional medicine \& pharmaceutical industry. It's health benefits that can be pointed include appetizing, stomach tonic, diuretic, anti-scurvy, mild anti-worm and induce of menstruation. Tarragon is used in traditional medicine for the resolution of joint pain, hiccups and treatment of painful menstruation. Despite contradictory statements, it was recently reported the tarragon extract is anticancer agent for some cancer cells line such as human leukemic cancer cells, human endometrial cancer cells, human breast cancer cells, etc. (Obolskiy et al., 2011).

Saline soil and saline irrigation are one of the most important environmental stresses, particularly in arid and semi-arid regions (Greenway and Munns, 1980; Kuznetsov and Shevyakova, 1997). Salt stress during vegetative and reproductive stage reduces crops biomass and yield (Aslam et al., 1993). Salinity affects plant growth and metabolism through disturbing several physiological processes of plants (Levitt, 1980; Hoshida et al., 2000). The first effect of salinity on plants is reducing water uptake even when the soil is completely wet, due to the decreased soil solution potential. Even more, cell membrane function may be damaged due to intracellular ion homeostasis disruption in plants exposed to salinity. Under these circumstances, some physiological disorders occur and programmed cell death imposed ultimately (Fan et al., 2013). Moreover, salt stress in plants leads to nutrients imbalance, reduction of the photosynthesis efficiency, increasing free radicals production such as superoxide anion $\left(\mathrm{O}_{2}{ }^{-}\right)$, hydrogen peroxide $\left(\mathrm{H}_{2} \mathrm{O}_{2}\right)$, hydroxyl radical $\left(\mathrm{OH}^{-}\right)$and singlet oxygen $\left({ }^{1} \mathrm{O}_{2}\right)$, and metabolic toxicity which causes the destruction of the cell membrane (Greenway and Munns, 1980; Fan, et al., 2013; Sankar, et al., 2007; Agarwal and Shaheen: 2007).

Plants responses to salinity stress are complex thus, salinity tolerance mechanisms are not clear yet. During the evolution and adaptation to salinity stress, various molecular mechanisms have been developed in plants for confronting the salinity. Some plants mechanisms cope with salinity by regulating ion homeostasis with accumulation of compatible solutes for osmotic adjustment, free radical scavenging, alterations in membrane structures, and phytohormone biosynthesis stimulation. It was also reported that the ion homeostasis was regulated via selective accumulation of ions, ion exclusion as well as limited ions uptake by root, ion transport to the leaves and that distribution at cellular and plant level (Fan et al., 2013; Hasegawa et al., 2000; Jaleel et al., 2007).

Some microorganisms such as plant growth promoting rhizobacteria and fungi, especially arbuscular mycorrhizal fungi (AMF), can improve the plant growth and crop yield in saline soils via alleviating destructive effects of salinity stress (Cho et al., 2006). Arbuscular mycorrhizal fungi inhabit the rhizosphere and have a symbiotic association with the roots of most terrestrial plant species (Gini et al., 2003; Smith and Read 1997). The most common AMF in saline soil are species from the genus Glomus (Ho, 1987; Wang et al., 2004). Molecular studies revealed that about $80 \%$ of fungi spores in saline soil belong to a single species, Glomus geosporum (T.H. Nicolson \& Gerd.) C. Walker (Wilde et al., 2009). Wu et al. (2010) reported that root inoculation of Citrus tangerina Tanaka by $G$. geosporum and Paraglomus occultum (C. Walker) J.B. Morton \& D. Redecker could improve growth, photosynthesis rate, root architecture, and ionic balance under $100 \mathrm{mM} \mathrm{NaCl}$. Kapoor et al. (2002) reported AMF diminished the adverse effects of salinity and thereby increased coriander (Coriandrum sativum L.) growth. However, the root inoculation of sour orange $(C$. aurantium $\mathrm{L}$.) and sweet orange $(C$. sinensis $(\mathrm{L}$.) Osbeck) by $G$. intraradices under the 30 , and $60 \mathrm{mM}$ salt had no effect on salinity tolerance, but the $\mathrm{Cl}^{-}$ concentration increased in root (Zou et al., 2013).

AMF can significantly improve resistance of host plants to varied biotic and abiotic stresses. Arbuscular mycorrhiza leads to better nutrients mobility in nutrient poor soils (Marschner and Dell, 1994). Thus, the growth of plants coexisted with AMF is enhanced due to the increased nutrients uptake, especially $\mathrm{N}$ and $\mathrm{P}$ (Marschner and Dell, 1994). However, the role of AMF in stress conditions and salinity may not be limited only to this nutritional effect (Ruiz-Lozano and Azcon, 2000). The tolerance mechanisms to salinity in plant symbiosis with AMF is consisted with improved osmotic potential adjustment, enhanced water use efficiency, production of plant growth hormones, reduced detrimental effect of oxidative stress, mitigation of toxic ion effects or improved nutritional status (Auge, 2001). According to reports on the alleviating detrimental salinity effects via the AMF root 
inoculation, this study was aimed for evaluation the qualitative and quantitative changes of tarragon yield under AMF (Glomus intraradices) inoculation and salinity condition.

\section{MATERIALS AND METHODS}

\subsection{Plant preparation and growth conditions}

This study was conducted in an experimental greenhouse of the Medicinal Plants Institute (MPI) affiliated with the Academic Center for Education, Culture and Research (ACECR) in Karaj as a factorial experiment in the randomized complete block design (RCBD) with 4 replications during 2015. The research station is located at $1472 \mathrm{~m}$ a. s. $1 ., 35^{\circ} 54^{\prime} \mathrm{N}$ and $50^{\circ} 53^{\prime}$ E. The same rooted transplants of tarragon (Artemisia dracunculus L. var. sativa) were provided from MPI seed bank (1096-MPISB), and were transferred into pots. Plants were grown in a plastic greenhouse for 3 months (from March 21 to June 20, 2015) with a photon flux density about $1300 \mu \mathrm{mol} \mathrm{m}{ }^{-2} \mathrm{~s}^{-1}, 16 \mathrm{~h}$ light and $8 \mathrm{~h}$ dark period and the average temperature of $21 / 16^{\circ} \mathrm{C}$ for day/night. The soil texture was loam-silt, its physiochemical properties contains $0.08 \%$ nitrogen, $36.2 \mathrm{ppm}$ phosphorus, $49.8 \mathrm{ppm}$ potassium, $7.9 \mathrm{pH}$, and electrical conductivity (EC) $1.2 \mathrm{dS} \mathrm{m}^{-1}$.

\subsection{Treatments}

Treatments included inoculation and non-inoculation with AMF (Glomus intraradices N.C. Schenck \& G.S. $\mathrm{Sm}$.$) as the first factor, and five salinity levels of$ irrigation water (with the EC of $0,2,4,6$, and $8 \mathrm{dS} \mathrm{m}^{-1}$ ) as the second factor. The leaching fraction equal 0.5 was used in irrigation practices in order to less salt accumulation. The electrical conductivity of the solutions was measured by EC meter (HI9811, Hanna, USA) and the salinity levels were kept constant throughout the experiment period for irrigation water. Same amount of irrigation water were applied for each treatment during the growing period. The salinity treatments began 30 days after transplanting via irrigation water with an interval every two days until the harvest time. The treatment solutions were made with saline water and distilled water depending on target salinity, while the control treatment of salinity was prepared with double distilled water. Natural saline water was obtained from Hoz-e-Soltan Lake in Qom, Iran. The major ions of the saline water were: $128 \mathrm{~g} \mathrm{l}^{-1}$ $\mathrm{Na}^{+}, 218.7 \mathrm{~g} \mathrm{l}^{-1} \mathrm{Cl}^{-}, 1.23 \mathrm{~g} \mathrm{l}^{-1} \mathrm{~K}^{+}, 19.5 \mathrm{~g} \mathrm{l}^{-1} \mathrm{Mg}^{2+}, 0.086$ $\mathrm{g} \mathrm{l}^{-1} \mathrm{Ca}^{2+}$, and $48.8 \mathrm{~g} \mathrm{l}^{-1} \mathrm{SO}_{4}^{2-}$.

For this experiment, 40 uniform plastic pots $(20 \mathrm{~cm}$ upper diameter $\times 15 \mathrm{~cm}$ bottom diameter $\times 18 \mathrm{~cm}$ height) as experimental plots were divided into subgroups with or without AMF inoculation. Inocula consisted of soil possessing fungal spores, hyphae and mycelium. According to the method of Tommerup
(1992), fungus identification was checked using light microscope (AXIO Imager; Carl Zeiss, Jena, Germany). AMF inoculum was multiplied in the open pots culture of sweet corn (Zea mays L. convar. saccharata var. rugosa Bonaf.) as a host and after six months of plant growth, the shoots were eliminated and the underground parts were stored for two months in polyethylene bags at $5{ }^{\circ} \mathrm{C}$. Thirty grams of the AMF inoculum (root fragments with $85 \%$ of colonized roots length) was added to $3.0 \mathrm{~kg}$ of autoclaved $\left(121^{\circ} \mathrm{C}, 0.11 \mathrm{MPa}, 1 \mathrm{~h}\right)$ soil for AMF inoculation (Carretero et al., 2008). Nonmycorrhizal treatments received the same amount of autoclaved AMF inoculum.

\subsection{Essential oils analysis}

The harvested plant materials of tarragon were air-dried in a shaded place at a convenient temperature $(24 \pm 2$ ${ }^{\circ} \mathrm{C}$ ) during 6 days. Essential oils of the aerial parts were extracted by hydro-distillation method for $3 \mathrm{~h}$ using Clevenger-type apparatus. The essential oils were dried over anhydrous sodium sulfate and kept on $4{ }^{\circ} \mathrm{C}$ until further analysis (British Pharmacopoeia, 1988). The extracted essential oils were identified by gas chromatography (GC) and gas chromatography coupled with mass spectrometry (GC/MS) analysis. GC/MS analysis was carried out on an Agilent instrument coupled with a Agilent 5973N Mass system equipped with flame ionization detector (Hewlett-Packard Company, USA) and a SGE BPX5 capillary column (30 $\mathrm{m} \times 0.25 \mathrm{~mm} ; 0.25 \mu \mathrm{m}$ film thicknesses, Kinesis Ltd., UK). Temperature program included: an oven temperature held for 5 minutes at $50^{\circ} \mathrm{C}$ and enhanced to $240{ }^{\circ} \mathrm{C}$ with $3{ }^{\circ} \mathrm{C}$ per min rate. Then, enhancement of temperature was programmed up to $300{ }^{\circ} \mathrm{C}$ with $15{ }^{\circ} \mathrm{C}$ per min rate and this temperature was held for 3 minutes. Other operating conditions include: carrier gas was $\mathrm{He}$ with a flow rate of $0.5 \mathrm{ml} \mathrm{min}{ }^{-1}$; injector and detector temperatures were $290^{\circ} \mathrm{C}$, and split ratio, 1:25. Mass spectra were taken at $70 \mathrm{eV}$ (Socaci et al., 2008). The components of the essential oils were identified by comparison of their mass spectra and retention indices with those published in the literature and presented in the MS computer library (Adams, 2001).

\subsection{Measurements and statistical analysis}

The sampling was conducted in the onset of flowering stage as all plants were harvested 93 days after transplanting. For future accuracy and to reduce errors, samples were picked in four replicates randomly from the separate experimental plot. The analyzed morpho- 
physiological traits were plant height, the number of leaves, SPAD value, leaf dry mass, shoot dry mass. The SPAD values were recorded using a SPAD-502 meter (Konica-Minolta, Japan). All the data were subjected to statistical analysis (one-way ANOVA) using SAS software (Ver. 9.2). The difference between treatments means was compared by Duncan's multiple range test at $5 \%$ confidence interval.

\section{RESULTS AND DISCUSSION}

Results showed that the AMF inoculation had a significant effect on the plant height $(p \leq 0.05)$, number of leaves, SPAD value, and leaf and shoot dry mass $(p \leq$ $0.01)$. Also, analysis of variance showed that different levels of salinity had a significant $(p \leq 0.01)$ effect on these traits. Between the salt stress and AMF inoculation was observed a significant interaction in the number of leaves $(p \leq 0.05)$, leaf and shoot dry mass ( $p$ $\leq 0.01)$ (Table 1).

Table 1: Analysis of variance for the effects of arbuscular mycorrhizal fungi (AMF), Glomus intraradices inoculation and salinity on morpho-physiological traits of tarragon

\begin{tabular}{|c|c|c|c|c|c|c|c|}
\hline \multirow[b]{2}{*}{ S.O.V. } & \multirow[b]{2}{*}{ Df. } & \multicolumn{6}{|l|}{ Mean Square } \\
\hline & & Plant height & $\begin{array}{l}\text { Number } \\
\text { leaves }\end{array}$ & of & Leaf dry mass & $\begin{array}{c}\text { Shoot } \\
\text { mass }\end{array}$ & SPAD value \\
\hline Replication & 3 & $8.99^{\mathrm{ns}}$ & $91.6^{\mathrm{ns}}$ & & $0.005^{*}$ & $0.005^{*}$ & $9.76^{\mathrm{ns}}$ \\
\hline AMF inoculation & 1 & $190.14^{*}$ & $11262.4^{* * *}$ & & $0.22^{* *}$ & $0.51^{\text {** }}$ & $106.27^{* *}$ \\
\hline Salinity (S) & 4 & $109.9^{* *}$ & $1828.4^{* *}$ & & $0.03^{* *}$ & $0.075^{* *}$ & $48.92^{* *}$ \\
\hline $\mathrm{AMF} \times(\mathrm{S})$ & 4 & $47.68^{\mathrm{ns}}$ & $154.4^{*}$ & & $0.026^{* *}$ & $0.139^{* *}$ & $16.69^{\mathrm{ns}}$ \\
\hline Error & 27 & 26.07 & 51.37 & & 0.0016 & 0.0078 & 7.22 \\
\hline CV ( \%) & & 8.84 & 6.47 & & 7.22 & 10.02 & 7.34 \\
\hline
\end{tabular}

ns: non-significant differences; ${ }^{*}:$ significant at $p \leq 0.05 ;{ }^{* * *}$ : significant at $p \leq 0.01$.

The plant height and SPAD value were increased for 7.8, and 9.3 percentage by AMF inoculation, respectively (Figure 1), but their amount were decreased under salinity condition. In comparison with the control treatment, the plant height and SPAD values were significantly reduced with increasing salinity to 4 and $6 \mathrm{dS} \mathrm{m} \mathrm{m}^{-1}$, what indicated that the leaf chlorophyll was more susceptible to raise of salinity (Figure 2, 3). These results also confirm the finding of other studies (Bernstein et al., 2010; Dolataadian et al., 2011; Amira and Qados, 2011; Mukhtar balal et al., 2011). Reduced osmotic potential in salinity condition is resulted in arrest of cell division and elongation (Jacoby, 1994). In addition, $\mathrm{Na}^{+}$and $\mathrm{Cl}^{-}$accumulation have toxic effects on the cell division and photosynthetic system, a reason for reduced plants growth. Also, salinity stress reduced biosynthesis and transport of cytokinin and gibberellin, but ABA biosynthesis was increased. These factors are contributing to the reduction of plant height under salt stress compared to control (Jacoby, 1994). Destruction of chloroplasts, chlorophyll photo-oxidation and prevented chlorophyll biosynthesis are the main reasons for the decline in content of photosynthetic pigments under salinity conditions (Sultan, 2005). It has also been reported that reduced chlorophyll amount is a consequence of increased chlorophyllase activity under salt stress (Reddy and Vora, 2005). Glutamate is a precursor for proline and chlorophyll biosynthesis. Thus, increased proline production in salt stress decreases glutamate availability in the chlorophyll biosynthesis (Drazkiewicz, 2000). 
- AMF inoculation AMF non-inoculation

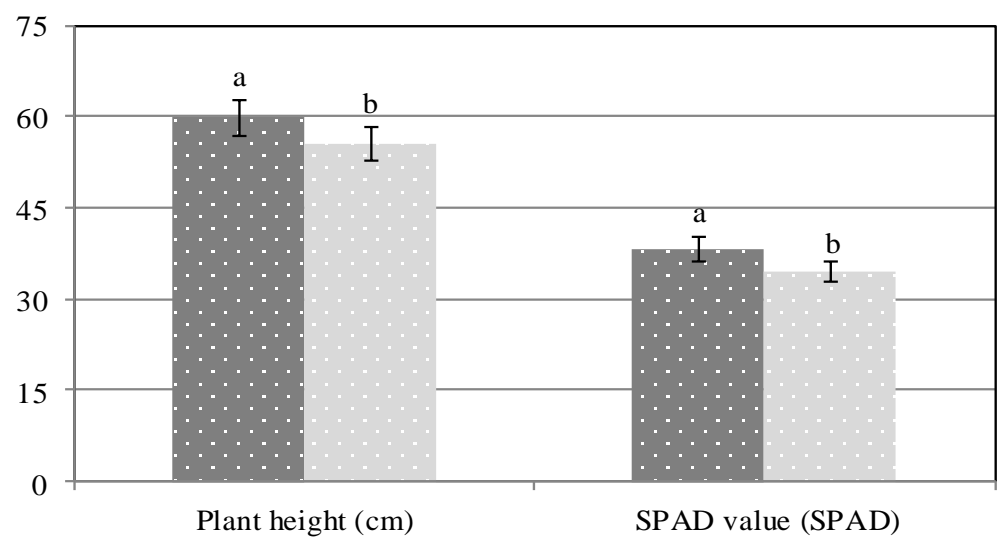

Figure 1: Effect of arbuscular mycorrhizal fungi (AMF), Glomus intraradices inoculation on plant height (cm), and SPAD value (SPAD). The vertical bars represent standard errors of the means

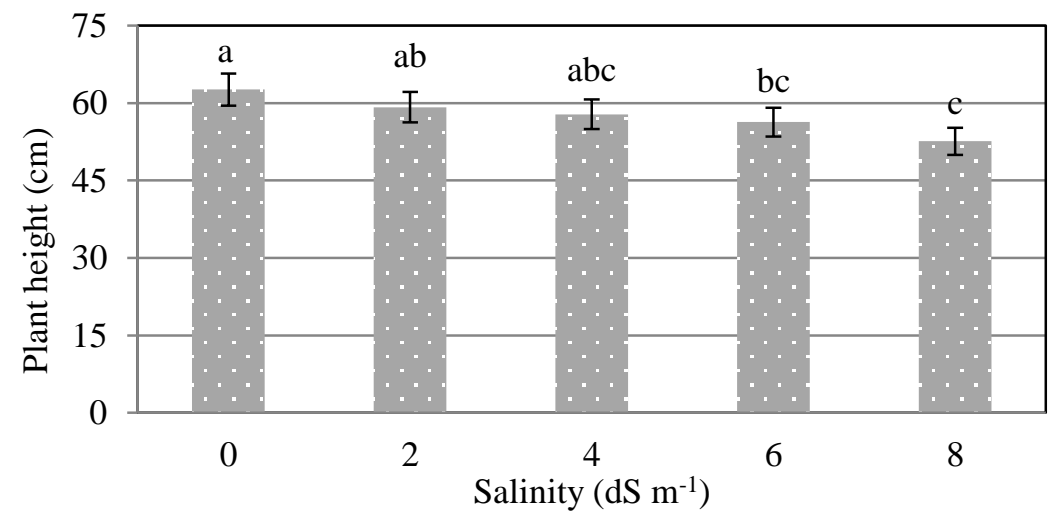

Figure 2: Effect of irrigation water salinity on plant height $(\mathrm{cm})$. The vertical bars represent standard errors of the means

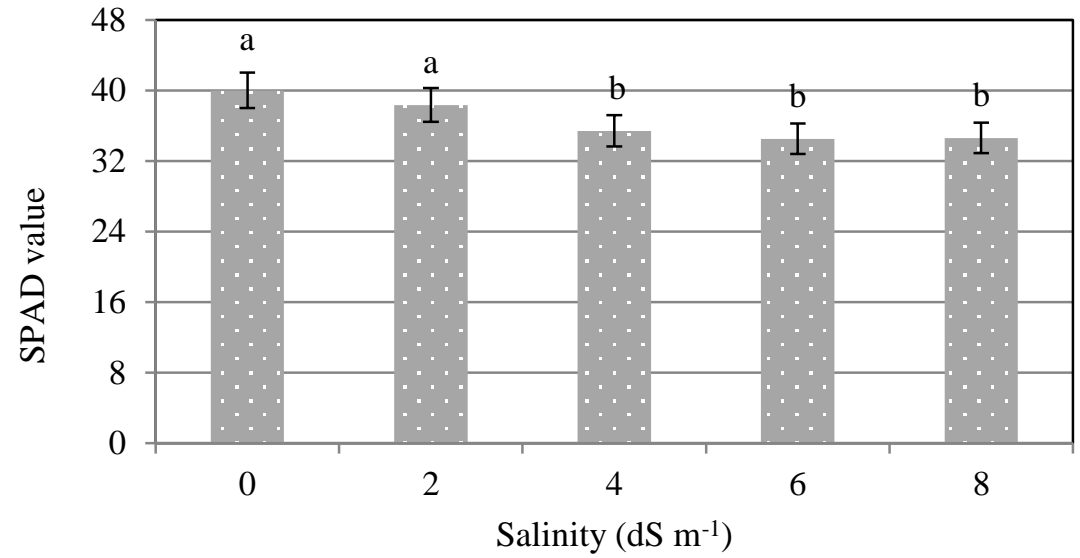

Figure 3: Effect of irrigation water salinity on SPAD value (SPAD). The vertical bars represent standard errors of the means 
The number of tarragon leaves was increased by AMF inoculation. However, the number of leaves was reduced through increasing salt concentration under either inoculation or non-inoculation of AMF. The highest number of leaves (with an average of 146.28) was observed in AMF inoculation without the salinity. However, the lowest of it (67.91) was obtained at the $6 \mathrm{dS} \mathrm{m}{ }^{-1}$ salinity without using the AMF (Figure 4). These findings confirm the results of other studies (Bernstein et al., 2010; Amira and Qados, 2011; Mukhtar balal et al., 2011). During salinity stress, plant leaf area was reduced due to smaller leaves formation and leaf abscission. Thus, the photosynthetic capacity diminished and the supply of assimilates for optimal growth was reduced. In addition, the rapid leaves senescence under salt stress caused the reduction of the leaf area durability (Munns, 1993).

Use of the AMF could ameliorate the tarragon leaf and shoot dry mass so that AMF inoculation in non-saline condition produced the greatest leaf dry mass $(0.76 \mathrm{~g})$ and its minimum $(0.39 \mathrm{~g})$ was observed in the $8 \mathrm{dS} \mathrm{m}^{-1}$ salinity without AMF inoculation (Figure 5). Similar to leaf dry mass, the highest shoot dry mass was obtained when the AMF inoculation was used in no-salinity stress $(1.33 \mathrm{~g})$ conditions and it's the least amounts was gained in the $8 \mathrm{dS} \mathrm{m}^{-1}$ salinity without AMF inoculation $(0.62 \mathrm{~g})$. Also, leaf and shoot dry mass were increased with increasing salinity to $4 \mathrm{dS} \mathrm{m} \mathrm{m}^{-1}$ withour AMF inoculation. In contrast, increasing salinity to more than $4 \mathrm{dS} \mathrm{m}^{-1}$ led to reduced leaf dry mass compared to the control (Figure 6). These findings are consistent with other studies (Kapoor et al., 2002; Ben Khaled et al., 2003; Rabie and Almadini, 2005; Gupta and Rutaray, 2005; Saleh and Al-Garni, 2006; Porras-Soriano et al., 2009).
Plant dry mass reduction in saline conditions is a response to spent metabolic energy for coping with the salt stress (Parida and Das, 2005). Main factors that influenced the plant dry mass consisted of reduced leaf area, increased chlorophyll destruction, reduced photosynthesis rate, toxic effects of $\mathrm{Na}^{+}$and $\mathrm{Cl}^{-}$ accumulation, decreased water uptake, and imbalance in nutrients (Sankar et al., 2007; Agarwal and Shaheen, 2007; Verma and Mishra, 2005). However, some authors reported that phosphorous nutrition can reduce the detrimental effects of salinity stress on plant growth. Therefore, AMF with increased phosphorous uptake can ameliorate for the harmful effects of salinity stress. On the other hand, the potassium content was increased in AMF inoculated plants. Thus, it protected host plant against adverse effect to sodium through enhanced potassium to sodium ratio (Marschner and Dell, 1994; Ruiz-Lozano and Azcon, 2000; Jeffries et al., 2003). Also, it was reported that use of AMF in lettuce is the reason for the roots extension. In addition, the photosynthesis rate and water use efficiency were improved, while the evapotranspiration was reduced (Ruiz- Lozano et al., 1996).

The tarragon essential oil content in this study was linearly reduced by the increased salinity. The AMF inoculation in various salinity levels reduced the essential oil content more than when AMF was not used, especially under the $8 \mathrm{dS} \mathrm{m}^{-1}$ salinity. Therefore, the greatest content $(1.15 \%)$ of essential oil was obtained in the AMF inoculation under no salinity condition, while its minimum $(0.2 \%)$ was acquired in the AMF inoculation along with the $8 \mathrm{dS} \mathrm{m}^{-1}$ salinity (Figure 7).

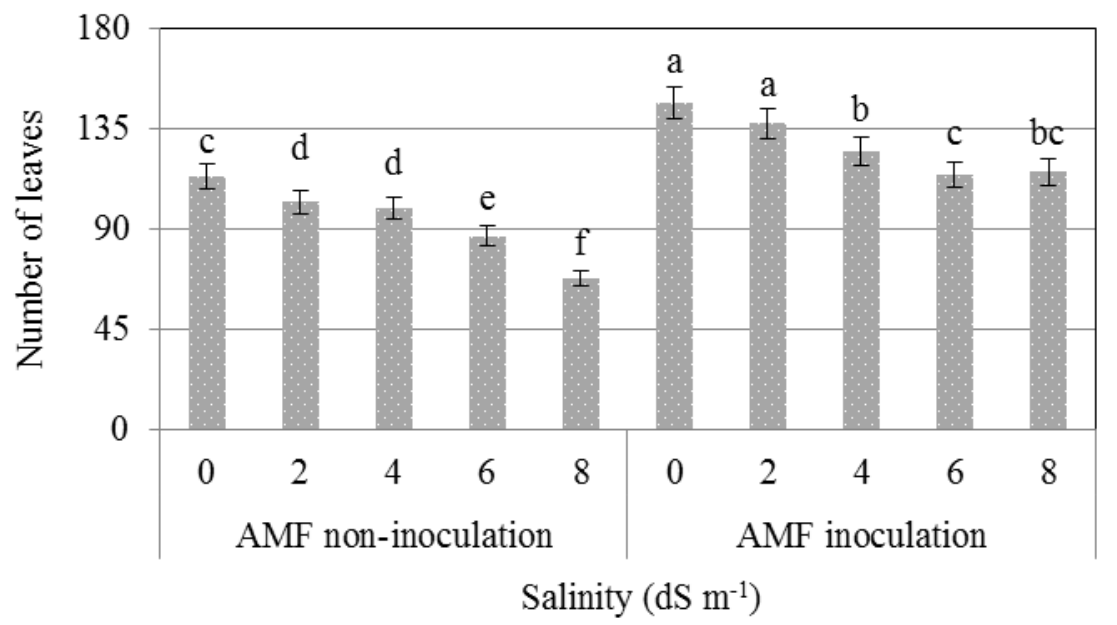

Figure 4: Effect of irrigation water salinity and arbuscular mycorrhizal fungi (AMF), Glomus intraradices inoculation on number of leaves. The vertical bars represent standard errors of the means 


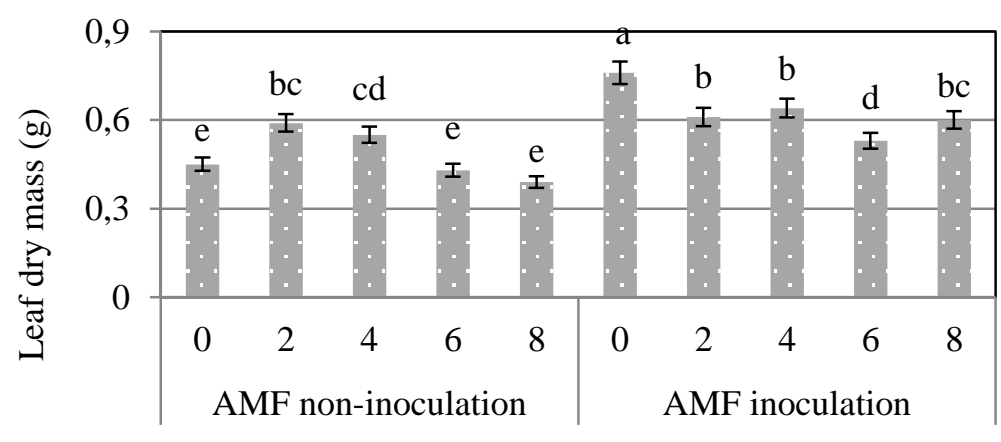

Salinity $\left(\mathrm{dS} \mathrm{m} \mathrm{m}^{-1}\right)$

Figure 5: Effect of irrigation water salinity and arbuscular mycorrhizal fungi (AMF), Glomus intraradices inoculation on leaf dry mass $(\mathrm{g})$. The vertical bars represent standard errors of the means

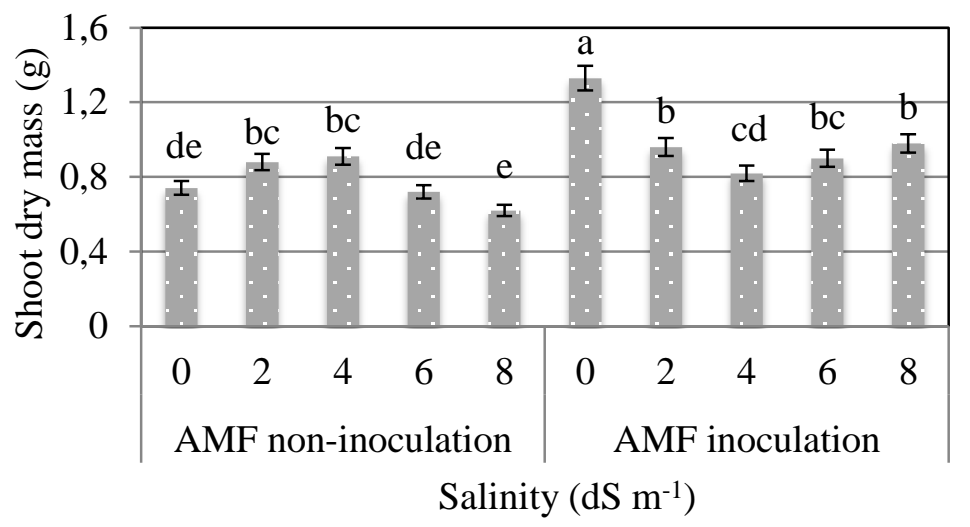

Figure 6: Effect of irrigation water salinity and AMF inoculation on shoot dry mass (g). The vertical bars represent standard errors of the means

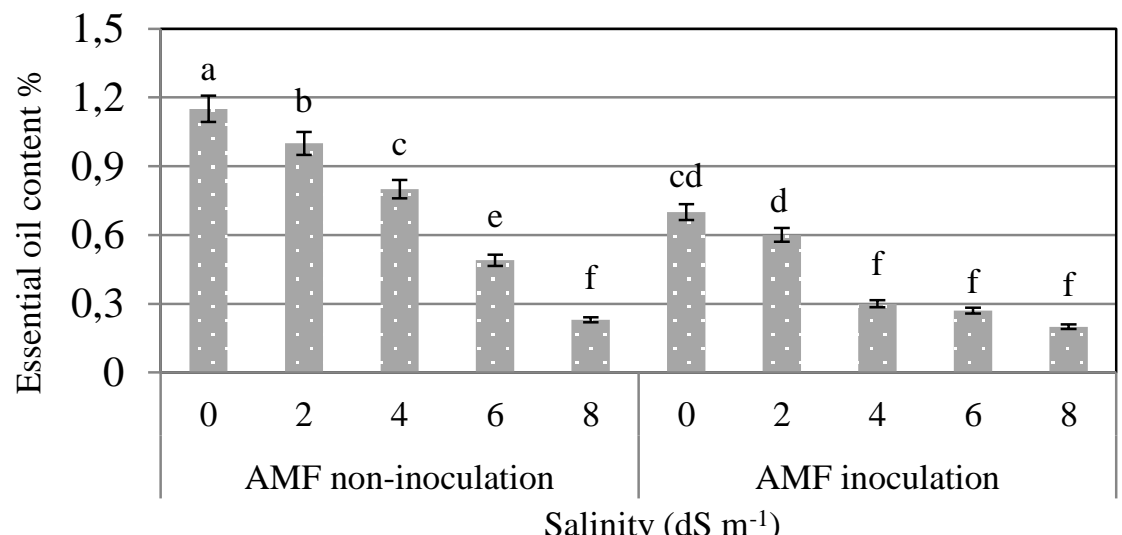

Figure 7: Effect of irrigation water salinity and arbuscular mycorrhizal fungi (AMF), Glomus intraradices inoculation on essential oil content ( \%). The vertical bars represent standard errors of the means 
Results showed that the effect of salinity on essential oil components was also dependent on the salt concentration. The content of $\alpha$-pinene, limonene, $Z$ and $E$-ocimene were increased at 2 and $4 \mathrm{dS} \mathrm{m}^{-1}$ salinity, but their content decreased when the salt concentration increased to over $4 \mathrm{dS} \mathrm{m}^{-1}$ compared to the control treatment. The amounts of these compounds were increased by AMF inoculation in non-salinity stress, but using AMF in 2 and $4 \mathrm{dS} \mathrm{m}^{-1}$ salinity reduced their content. Use of AMF had no significant difference with AMF non-inoculation in 6 and $8 \mathrm{dS} \mathrm{m}^{-1}$ salinity. The highest content of $\alpha$-pinene $(1.03 \%)$, limonene (3.22\%), $Z$ and $E$-ocimene (6.35 and $7.31 \%$ ) were obtained under $2 \mathrm{dS} \mathrm{m}^{-1}$ salinity without AMF inoculation and the lowest amount of these compounds were obtained in the $4 \mathrm{dS} \mathrm{m} \mathrm{m}^{-1}$ salinity with AMF application $(0.1,0.47,0.91$, and $0.77 \%$, respectively) (Table 3).

The content of methyl chavicol had no significant difference with the control up to $6 \mathrm{dS} \mathrm{m}^{-1}$ salinity, but it was significantly reduced at the $8 \mathrm{dS} \mathrm{m}^{-1}$ salinity. AMF application in control and under $8 \mathrm{dS} \mathrm{m}^{-1}$ salinity increased methyl chavicol content. However, in the other grades of salinity there was not a significant difference between AMF inoculation and noninoculation. The maximum and minimum methyl chavicol content were gained in AMF inoculation and control treatment $(88.8 \%)$, and non-application of AMF under $8 \mathrm{dS} \mathrm{m}^{-1}$ salinity $(64.3 \%)$ (Table 3$)$.

The amount of bornyl acetate was increased under salinity with AMF inoculation. Its highest content $(0.73 \%)$ was observed in the AMF inoculation with the $8 \mathrm{dS} \mathrm{m}^{-1}$ salinity and its minimum content $(0.08 \%)$ was obtained in AMF non-inoculation with control treatment of salinity. The content of eugenol, methyl eugenol, caryophyllene, germacrene, and $\alpha$-farnesene was increased with increasing the level of salinity. Thus, their maximum content $(0.9,4.24,1.33,2.54$, and $2.64 \%$, respectively) was observed under the $8 \mathrm{dS} \mathrm{m}^{-1}$ salinity. Moreover, their minimum content $(0.11,0.61$, $0.13,0.41$, and $0.06 \%$, respectively) was obtained in the control without AMF inoculation. The amounts of these compounds were elevated with increasing the salinity up to $6 \mathrm{dS} \mathrm{m}^{-1}$ when AMF inoculated. But their content was significantly reduced when the salinity increased to the $8 \mathrm{dS} \mathrm{m}^{-1}$ (Table 3).

In summary, the various salinity levels decreased the tarragon essential oil content and the content of $\alpha$ pinene, limonene, $Z$-ocimene, $E$-ocimene, and methyl chavicol, while the content of bornyl acetate, eugenol, methyl eugenol, caryophyllene, germacrene, and $\alpha$ farnesene was increased. Similar results were obtained also by other authors (Ashraf and Orooj, 2006; Tabatabaie and Nazari, 2007; Aziz et al., 2008; Belaqziz et al., 2009; Baatour et al., 2010). Salinity could directly influence essential oil content and its components via changing the activity of the enzymes which are responsible for the terpenoids or phenylpropanoid biosynthesis and by altering the abscisic acid to cytokinins ratio. Furthermore, impaired photosynthesis and carbohydrate production indirectly affect the essential oil content and its components (Safarnejad et al., 2006; Turkan, 2011). It is reported that under the salinity stress, the biosynthesis of monoterpene biosynthesis is more affected than sesquiterpenes due to energy shortages thus, monoterpene biosynthesis is more vulnerable to salinity stress (Turner and Croteau, 2004). However, that the reduced ratio of oxygenated monoterpene to sesquiterpenes is caused by changes in cell bioenergetics under environmental stress. Another factor involved in this issue is the difference in the position of the compounds biosynthesis in using oxygen and energy resources (Dudareva et al., 2004).

The AMF inoculation in various levels of salinity resulted in reduced content of essential oils and a number of its major components, while the content of methyl chavicol, bornyl acetate, and caryophyllene was increased. Ahmadi-Khoei et al. (2013) reported similar results that the stimulation and changes in essential oil and phenol biosynthesis through fungal inoculation are possible. 
Table 2: Analysis of variance for effects of arbuscular mycorrhizal fungi (AMF), Glomus intraradices inoculation and salinity on phytochemical traits of tarragon

\begin{tabular}{llllllll}
\hline \multicolumn{7}{c}{ Mean Square } \\
\cline { 3 - 7 } S.O.V. & Df. & $\begin{array}{c}\text { Essential oil } \\
\text { content }\end{array}$ & $\alpha$-pinene & limonene & Z-ocimene & E-ocimene & $\begin{array}{c}\text { methyl } \\
\text { chavic } \\
\text { ol }\end{array}$ \\
\hline Replication & 3 & $0.002^{\text {ns }}$ & $0.007^{* *}$ & $0.026^{* *}$ & $0.18^{\text {ns }}$ & $0.018^{\text {ns }}$ & $5.92^{\text {ns }}$ \\
AMF inoculation & 1 & $1.02^{* *}$ & $0.67^{* *}$ & $1.3^{* *}$ & $37.71^{* *}$ & $42.47^{* *}$ & $306.42^{* *}$ \\
Salinity (S) & 4 & $0.68^{* *}$ & $0.12^{* *}$ & $0.35^{* *}$ & $16.58^{* *}$ & $24.94^{* *}$ & $194.9^{* *}$ \\
AMF $\times(S)$ & 4 & $0.074^{* *}$ & $0.28^{* *}$ & $0.81^{* *}$ & $21.31^{* *}$ & $26.8^{* *}$ & $160.51^{* *}$ \\
Error & 27 & 0.005 & 0.0008 & 0.0038 & 0.067 & 0.066 & 27.68 \\
CV $(\%)$ & & 12.39 & 3.97 & 5.18 & 7.71 & 7.33 & 6.74 \\
\hline
\end{tabular}

ns: non-significant differences; ${ }^{*}$ : significant at $p \leq 0.05 ;{ }^{* *}$ : significant at $p \leq 0.01$.

Table 2: Continued

\begin{tabular}{|c|c|c|c|c|c|c|c|}
\hline \multirow[b]{2}{*}{ S.O.V. } & \multirow[b]{2}{*}{ Df. } & \multicolumn{6}{|l|}{ Mean Square } \\
\hline & & germacrene & caryophyllene & $\begin{array}{c}\text { methyl } \\
\text { euge } \\
\text { nol }\end{array}$ & eugenol & $\begin{array}{l}\text { bornyl } \\
\text { acetate }\end{array}$ & $\alpha$-farnesene \\
\hline Replication & 3 & $0.108^{* * *}$ & $0.005^{\mathrm{ns}}$ & $0.004^{\mathrm{ns}}$ & $0.0085^{* * 4}$ & $0.0008^{\mathrm{ns}}$ & $0.011^{\mathrm{ns}}$ \\
\hline AMF inoculation & 1 & $0.526^{* *}$ & $0.251^{* *}$ & $2.04^{* *}$ & $0.083^{* *}$ & $0.34^{* * *}$ & $1.42^{* *}$ \\
\hline Salinity (S) & 4 & $4.38^{* *}$ & $0.665^{* *}$ & $16.06^{* *}$ & $0.642^{* * *}$ & $0.24^{* *}$ & $6.14^{* *}$ \\
\hline $\mathrm{AMF} \times(\mathrm{S})$ & 4 & $0.78^{* *}$ & $0.075^{* *}$ & $2.19^{* * *}$ & $0.118^{* *}$ & $0.004^{* *}$ & $0.93^{* *}$ \\
\hline Error & 27 & 0.022 & 0.002 & 0.011 & 0.0015 & 0.0009 & 0.024 \\
\hline $\mathrm{CV}(\%)$ & & 11.15 & 5.8 & 5.11 & 9.089 & 7.57 & 10.95 \\
\hline
\end{tabular}

ns: non-significant differences; ${ }^{*}$ : significant at $p \leq 0.05 ;{ }^{* *}$ : significant at $p \leq 0.01$. 
Amin LAMIAN et. al

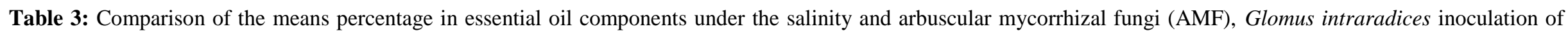
tarragon

\begin{tabular}{|c|c|c|c|c|c|c|c|c|c|c|c|c|}
\hline $\mathrm{AMF}$ & Salinity & $\alpha$-pinene & limonene & Z-ocimene & $E$-ocimene & $\begin{array}{c}\text { methyl } \\
\text { chavi } \\
\text { col }\end{array}$ & $\begin{array}{l}\text { bornyl } \\
\text { aceta } \\
\text { te }\end{array}$ & eugenol & $\begin{array}{l}\text { methyl } \\
\text { eugeno } \\
1\end{array}$ & caryophyllene & germacrene & $\begin{array}{l}\alpha- \\
\quad \begin{array}{l}\text { farnes } \\
\text { ene }\end{array}\end{array}$ \\
\hline \multirow{5}{*}{$\begin{array}{l}\text { Non- } \\
\text { inoculati } \\
\text { on }\end{array}$} & 0 & $0.72^{c}$ & $2.16^{\mathrm{c}}$ & $4.98^{\mathrm{c}}$ & $5.5^{c}$ & $75.9^{b c}$ & $0.08^{g}$ & $0.11^{\mathrm{g}}$ & $0.61^{\mathrm{f}}$ & $0.13^{\mathrm{f}}$ & $0.41^{\mathrm{f}}$ & $0.07^{\mathrm{f}}$ \\
\hline & 2 & $1.03^{\mathrm{a}}$ & $3.22^{\mathrm{a}}$ & $6.35^{\mathrm{a}}$ & $7.31^{\mathrm{a}}$ & $83.4^{\mathrm{ab}}$ & $0.21^{\mathrm{f}}$ & $0.11^{\mathrm{g}}$ & $0.65^{\mathrm{f}}$ & $0.3^{\mathrm{e}}$ & $0.57^{\text {ef }}$ & $0.8^{\mathrm{d}}$ \\
\hline & 4 & $0.95^{\mathrm{b}}$ & $2.57^{\mathrm{b}}$ & $6.29^{\mathrm{ab}}$ & $6.38^{\mathrm{b}}$ & $76.4^{\mathrm{bc}}$ & $0.28^{\mathrm{e}}$ & $0.13^{g}$ & $0.75^{\mathrm{f}}$ & $0.31^{\mathrm{e}}$ & $0.72^{\mathrm{e}}$ & $0.59^{\mathrm{de}}$ \\
\hline & 6 & $0.58^{\mathrm{d}}$ & $0.71^{\mathrm{e}}$ & $1.33^{\mathrm{e}}$ & $1.11^{\mathrm{f}}$ & $75.9^{\mathrm{bc}}$ & $0.42^{\mathrm{d}}$ & $0.68^{\mathrm{b}}$ & $2.72^{c}$ & $0.92^{b c}$ & $1.81^{\mathrm{c}}$ & $1.99^{b}$ \\
\hline & 8 & $0.29^{\mathrm{f}}$ & $1.34^{\mathrm{d}}$ & $2.63^{\mathrm{d}}$ & $2.38^{\mathrm{d}}$ & $64.3^{\mathrm{d}}$ & $0.5^{\mathrm{bc}}$ & $0.9^{\mathrm{a}}$ & $4.24^{\mathrm{a}}$ & $1.33^{\mathrm{a}}$ & $2.54^{\mathrm{a}}$ & $2.64^{\mathrm{a}}$ \\
\hline \multirow{5}{*}{ Inoculation } & 0 & $0.88^{b}$ & $2.54^{b}$ & $5.96^{b}$ & $6.65^{b}$ & $88.8^{a}$ & $0.23^{\mathrm{f}}$ & $0.18^{\mathrm{f}}$ & $0.61^{\mathrm{f}}$ & $0.21^{\text {ef }}$ & $0.55^{\text {ef }}$ & $0.51^{\mathrm{e}}$ \\
\hline & 2 & $0.13^{\mathrm{g}}$ & $0.44^{\mathrm{f}}$ & $0.93^{\mathrm{f}}$ & $1^{\mathrm{f}}$ & $80.8^{\mathrm{b}}$ & $0.42^{\mathrm{d}}$ & $0.34^{\mathrm{e}}$ & $1.45^{\mathrm{e}}$ & $0.59^{\mathrm{d}}$ & $0.99^{\mathrm{d}}$ & $1.14^{\mathrm{c}}$ \\
\hline & 4 & $0.10^{g}$ & $0.47^{\mathrm{f}}$ & $0.91^{\mathrm{f}}$ & $0.77^{\mathrm{f}}$ & $83.4^{\mathrm{ab}}$ & $0.49^{c}$ & $0.5^{\mathrm{d}}$ & $1.96^{\mathrm{d}}$ & $0.88^{\mathrm{c}}$ & $1.67^{\mathrm{c}}$ & $1.79^{\mathrm{b}}$ \\
\hline & 6 & $0.39^{\mathrm{e}}$ & $0.92^{\mathrm{e}}$ & $1.64^{\mathrm{e}}$ & $1.57^{\mathrm{e}}$ & $71 .^{\mathrm{cd}}$ & $0.54^{b}$ & $0.73^{b}$ & $4.13^{\mathrm{a}}$ & $1.43^{\mathrm{a}}$ & $2.2^{b}$ & $2.58^{\mathrm{a}}$ \\
\hline & 8 & $0.3^{\text {ef }}$ & $1.35^{\mathrm{d}}$ & $2.43^{\mathrm{d}}$ & $2.38^{\mathrm{d}}$ & $79.5^{b}$ & $0.73^{\mathrm{a}}$ & $0.62^{c}$ & $3.08^{b}$ & $1.02^{\mathrm{b}}$ & $1.78^{\mathrm{c}}$ & $1.96^{b}$ \\
\hline
\end{tabular}

Means with the same letters in each column indicate no significant difference between treatments at the $5 \%$ level of probability. 


\section{CONCLUSION}

The morpho-physiological characteristics and essential oil content of tarragon were reduced under salinity stress, but some content of essential oil components were increased such as bornyl acetate, eugenol, methyl eugenol, caryophyllene, germacrene, and $\alpha$-farnesene. In general, the AMF inoculation in no salinity condition had the most positive effect on tarragon morpho- physiological traits and methyl chavicol amount. Although, the essential oil content was reduced with the AMF inoculation, but methyl chavicol amount as a major tarragon essential oil component was increased by the AMF inoculation under salinity condition. Therefore, we can conclude that the AMF inoculation caused to alleviate salinity stress harmful effects.

\section{REFERENCE}

Adams, R.P. (2001). Identification of essential oil components by gas chromatography/quadrupole mass spectroscopy. Allured Publishing, Carol Stream, IL, USA.

Agarwal, S., and Shaheen, R. (2007). Stimulation of antioxidant system and lipid peroxidation by abiotic stress in leaves of Momordica charantia. Brazilian Journal of Plant Physiology, 19(2), 149-161. doi:10.1590/S1677-04202007000200007

Ahmadi-Khoei, M., Shabani, L., Bagheri, S. (2013). Assay of phenolic compounds and essential oils in mycorrhizal mint genotypes. Iranian Journal of Plant Biology, 5(18), 81-93.

Amira, M.S., Qados, A. (2011). Effect of salt stress on plant growth and metabolism of bean plant Vicia faba (L.). Journal of the Saudi Society of Agricultural Sciences, 10(1), 7-15. doi:10.1016/j.jssas.2010.06.002

Ashraf, M., Orooj, A. (2006). Salt stress effects on growth, ion accumulation and seed oil concentration in an arid zone traditional medicinal plant ajwain (Trachyspermum ammi [L.] Sprague). Journal of Arid Environments, $\quad 64 \quad$ (2), 209-220. doi:10.1016/j.jaridenv.2005.04.015

Aslam, M., Qureshi, R.H., Ahmad, N.A. (1993). Rapid screening technique for salt tolerance in rice (Oryza sativa L.). Plant Soil, 150, 99-107. doi:10.1007/BF00779180

Auge, R.M. (2001). Water relations, drought and vesiculararbuscular mycorrhizal symbiosis. Mycorrhiza, 11, 342. doi: $10.1007 / \mathrm{s} 005720100097$

Aziz, E.E., Craker Al-Amier, H.L.E. (2008). Influence of salt stress on growth and essential oil production in peppermint, pennyroyal, and apple mint. Journal of Herbs, Spices \& Medicinal Plants, 14 (1 \& 2), 77 87. doi:10.1080/10496470802341375

Baatour, O., Kaddour, R., Aidi Wannes, W., Lachaa, M., Marzouk, B. (2010). Salt effects on the growth, mineral nutrition, essential oil yield and composition of marjoram (Origanum majorana). Acta Physiology Plant, 32, 45-51. doi:10.1007/s11738-009-0374-4
Belaqziz, R., Romane, A., Abbad, A. (2009). Salt stress effects on germination, growth and essential oil content of an endemic thyme species in Morocco (Thymus maroccanus Ball.). J. Applied Science Research, 5 (7), 858-863.

Ben Khaled, L., Gomes, A.M., Ouarraqi, E.M., Oihabi, A. (2003). Physiology and biochemical resposes to salt stress of mycorrhizal and/or nodulated clover seedling (Trifolium alexandrinum L.). Agronomy, 23, 571-580. doi:10.1051/agro:2003037

Bernstein, N., Kravchik, M., Dudai, N. (2010). Salinityinduced changes in essential oil, pigments and salts accumulation in sweet basil (Osimum basilicum) in relation to alteration of morphological development. Annals of Applied Biology, 156(2), 167-177. doi:10.1111/j.1744-7348.2009.00376.x

British Pharmacopoeia. (1988). Volume I. London. HMSO. p. A137-A138.

Carretero, C.L., Cantos, M., Garcia, J.L., Azcon, R., Troncoso, A. (2008). Arbuscular-Mycorrhizal Contributes to Alleviation of Salt Damage in Cassava Clones. Journal of Plant Nutrition, 31, 959-971. doi:10.1080/01904160802043296

Cho, K., Toler, H., Lee, J., Owenley, B., Stutz, J.C., Moore, J.L., Auge, R.M. (2006). Mycorrhizal symbiosis and response of sorghum plants to combined drought and salinity stresses. J. Plant Physiology, 163, 517-528. doi:10.1016/j.jplph.2005.05.003

Chopra, R.N., Nayar, S.L., Chopra, I.C. (1986). Glossary of Indian Medicinal Plants (Including the Supplement). Council of Scientific and Industrial Research, New Delhi.

Dolataadian, A., Modrres sanavyi, S.A.M., Ghanati, F. (2011). Effect of salinity on growth, xylem structure and anatomical characteristics of soybean. Notulae Scientia Biologicae, 3(1), 41-45.

Drazkiewicz, M. (2000). Chlorophyllase: occurrence, functions, mechanism of action, effects of external and internal factors. Photosynthesis, 30 (3), 321-331. 
Dudareva, N., Picheresky, E., Gershenzon, J. (2004). Biochemistry of plant volatiles. Plant Physiology, 134, 1893-1902. doi:10.1104/pp.104.049981

El-Amri, S.M., Al-Whaibi, M.H., Abdel-Fattah, G.M., Siddiqui, M.H. (2013). Role of mycorrhizal fungi in tolerance of wheat genotypes to salt stress. African Journal of Microbiology Research, 7(14), 1286-1295. doi:10.5897/AJMR12.2332

Fan, H.F., Du, C.X., Guo, S.R. (2013). Nitric oxide enhances salt tolerance in cucumber seedlings by regulating free polyamine content. Environmental and Experimental Botany, 86, 52-59. doi:10.1016/j.envexpbot.2010.09.007

Fernandez-Lizarazo, J.C., Mosquera-Vasquez, T., Chaves, B., Sarmiento, F. (2011). Phyllochron and differential growth between plants of French tarragon (Artemisia dracunculus L.) with different source of propagation. Agronomía Colombiana, 29(3), 387-397.

Gini, B., Kapoor, R., Mukerji, K.G. (2003). Influence of arbuscular mycorrhizal fungi and salinity on growth, biomass and mineral nutrition of Acacia auriculiformis. Biology and Fertility of Soils, 38, 170175. doi:10.1007/s00374-003-0636-z

Greenway, H., Munns, R. (1980). Mechanisms of salt tolerance in nonhalophytes. Annual Review of Plant Biology, 31, 149-190. doi:10.1146/annurev.pp.31.060180.001053

Gupta, N., Rutaray, S. (2005). Growth and development of AM fungi and maize under salt and acid stress. Acta Agricultural Scandinavia, Section B, Soil and Plant Science, $\quad 55, \quad 151-157$. doi:10.1080/09064710510008694

Hasegawa, P.M., Bressan, R.A., Zhu, J.K., Bohnert, H.J. (2000). Plant cellular and molecular responses to high salinity. Annual review of plant physiology and plant molecular biology. 51, 463-499. doi:10.1146/annurev.arplant.51.1.463

Ho, I. (1987). Vesicular-arbuscular mycorrhizae of halophytic grasses in the Alvord desert of Oregon. Northwest Science, 61, 148-151.

Hoshida, H., Tanaka, Y., Hibino, T., Hayashi, Y., Tanaka, A., Takabe, T. (2000). Enhanced tolerance to salt stress in transgenic rice that over expresses chloroplast glutamine synthetase. Plant Molecular Biology, 43, 103-111. doi:10.1023/A:1006408712416

Jacoby, B. (1994). Mechanisms involved in salt tolerance by plants. In: Pessarakli, M. (Ed.), Handbook of Plant and Crop Stress. Marcel Dekker, New York, pp. 97123.

Jaleel, C.A., Gopi, R., Sankar, B., Manivannan, P., Kishorekumar, A., Sridharan, R., Panneerselvam, R. (2007). Studies on germination, seedling vigour, lipid peroxidation and proline metabolism in Catharanthus roseus seedlings under salt stress. South African
Journal of Botany, 73, 190-195. doi:10.1016/j.sajb.2006.11.001

Jeffries, P., Gianinazzi, S., Perotto, S., Turnau, K., Barea, J.M. (2003). The contribution of arbuscular mycorrhizal fungi in sustainable maintenance of plant health and soil fertility. Biology and Fertility of Soils, 37, 1-16. doi: 10.1007/s00374-002-0546-5

Kapoor, R., Giri, B., Mukerji, G. (2002). Mycorrhization of coriander (Coriandrum sativum L.) to enhance the concentration and quality of essential oil. Journal of the Science of Foot and Agriculture, 82, 339-342. doi:10.1002/jsfa.1039

Kuznetsov, V.V., Shevyakova, N.I. (1997). Stress responses of tobacco cells to high temperature and salinity. Proline accumulation and phosphorylation of polypeptides. Physiologia Plantarum, 100, 320-326. doi:10.1111/j.1399-3054.1997.tb04789.x

Levitt, J. (1980). Salt and ion stresses in: Responses of plant to environmental stress. Academic Press, INC. 2, 365-406.

Marschner, H., Dell, B. (1994). Nutrient uptake in mycorrhizal symbiosis. Plant Soil, 159, 89-102. doi:10.1007/BF00000098

Mukhtar balal, R., Ashraf, M.Y., Khan, M.M., Jaskani, M.J., Ashfaq, M. (2011). Influence of salt stress on growth and biochemical parameters of citrus rootstocks. Pakistan Journal of Botany, 43(4), 21352141.

Munns, R. (1993). Physiological processes limiting plant growth in saline soils: some dogmas and hypotheses. Plant cell environment. 16, 15-24. doi:10.1111/j.13653040.1993.tb00840.x

Obolskiy, D., Pischel, I., Feistel, B., Glotov, N., Heinrich, M. (2011). Artemisia dracunculus L. (tarragon): a critical review of its traditional use, chemical composition, pharmacology, and safety. Journal of Agricultural and Food Chemistry, 59(21), 11367-84. doi:10.1021/jf202277w

Parida, A.K., Das, A.B. (2005). Salt tolerance and salinity effects on plants. Ecotoxicology and Environmental Safety, 60(3), 324-349. doi:10.1016/j.ecoenv.2004.06.010

Porras-Soriano, A., Soriano-Martin, M.L., Porras-Piedra, A., Azcon, R. (2009). Arbuscular mycorrhizal fungi increased growth, nutrient uptake and tolerance to salinity in olive trees under nursery conditions. $J$. Plant Physiology, 166, 1350-59. doi:10.1016/j.jplph.2009.02.010

Rabie, G.H., Almadini, A.M. (2005). Role of bioinoculants in development of salt-tolerance of Vicia faba plants under salinity stress. African Journal of Biotecnology, 4(3), 210-222. 
Reddy, M.P., Vora, A.B. (2005). Salinity induced changes in pigment composition and chlorophyllase activity of chelidonium. Indian Journal Plant Physiology, 29(4), 331-334.

Ruiz-Lozano, J.M., Azcon, R. (2000). Symbiotic efficiency and infectivity of an autochthonous arbuscular mycorrhizal Glomus sp. from saline soils and Glomus deserticola under salinity. Mycorrhiza, 10, 137-143. doi: $10.1007 / \mathrm{s} 005720000075$

Ruiz-Lozano, J.M., Azcon, R., Gomes, M. (1996). Alleviation of salt stress by arbuscular mycorrhizal Glomus species in Lactuca sativa plants. Physiologia Plantarum, 98, 767-772. doi.10.1111/j.13993054.1996.tb06683.x

Safarnejad, A., Salami, M.R., Hamidi, H. (2006). Morphological characterization of medicinal plants (Plantago ovata, and Plantago psyllium) in response to salt stress. Pajouhesh \& Sazandegi, 75, 152-160.

Saleh, M., Al-Garni, S. (2006). Increased heavy metal tolerance of cowpea plant by dual inoculation of an arbuscular mycorrhizal fungi and nitrogen-fixer Rhizobium bacterium. African Journal of Biotechnology, 5(2), 133-142.

Sankar, B., Jaleel, C.A., Manivannan, P., Kishorekumar, A., Somasundaram, R., Panneerselvam, R. (2007). Drought induced biochemical modifications and proline metabolism in Abelmoschus esculentus L. Moench. Acta Botanica Croatica, 66, 43-56.

Smith, S.E., Read, D.J. (1997). Mycorrhizal symbiosis. Academic Press, San Diego, CA. 605.

Socaci, S.A., Tofana, M., Socaciu, C. (2008). GC-MS Analysis of rosemary essential oil. Bulletin UASVM Agriculture, 65(2), 405 - 409.

Sultan, A. (2005). Effect of $\mathrm{NaCl}$ salinity on photosynthesis and dry matter accumulation in developing rice grains. Environmental and Experimental Botany, 42(3), 211-220. doi.10.1016/S0098-8472(99)00035-0

Tabatabaie, S.J., Nazari, J. (2007). Influence of nutrient concentration and $\mathrm{NaCl}$ salinity on growth, photosynthesis and essential oil content of peppermint and lemon verbena Search Results. Turkish Journal of Agriculture and Forestry, 31, 245-253.

Tommerup, I.C. (1992). Methods for the study of the population biology of vesicular-arbuscular mycorrhizal fungi. In: Techniques for the Study of Mycorrhiza, Part II, Volume 24 (Methods in
Microbiology). Ed. By: Norris JR, Read DJ, and Varma AK. Academic Press Limited. 24, 23-51. ISBN; 0-12-521524-X. doi:10.1016/S05809517(08)70085-0

Turkan, I. (2011). Plant responses to drought and salinity stress: Development in a post-genomic era. Series: advances in botanical research. Academic press, Elsevier Ltd. USA. Vol. 57 ( $1^{\text {st }}$ Edition), 592 p. eBook ISBN; 9780123876829.

Turner, G.W., Croteau, R. (2004). Organization of monoterpene biosynthesis in Mentha: Immunocytochemical localizations of geranyl diphosphate synthase, limonene-6-hydroxylase, isopiperitenol dehydrogenase, and pulegone reductase. Plant Physiology, 136, 4215-4227. doi.10.1104/pp.104.050229

Verma, M.K., Anand, R., Chisti, A.M., Kitchlu, S., Chandra, S., Shawl, A.S., Khajuria, R.K. (2010). Essential Oil Composition of Artemisia dracunculus L. (Tarragon) Growing in Kashmir - India. Journal of essential oil-bearing plants, 13(3), 331-335. doi:10.1080/0972060X.2010.10643830

Verma, S., Mishra, N. (2005). Putrescine alleviation of growth in salt stressed Brassica juncea by inducing antioxidative defence system. Journal of Plant Physiology, 162(9), 669-677. doi.10.1016/j.jplph.2004.08.008

Wang, F.Y., Liu, R.J., Lin, X.G., Zhou, J.M. (2004). Arbuscular mycorrhizal status of wild plants in salinealkaline soils of the Yellow River Delta. Mycorrhiza, 14, 133-137. doi:10.1007/s00572-003-0248-3

Wilde, P., Manal, A., Stodden, M., Sieverding, E., Hilderbrandt, U., Bothe, H. (2009). Biodiversity of arbuscular mycorrhizal fungi in roots and soils of two salt marshes. Environmental Microbiology, 11, 1548156. doi:10.1111/j.1462-2920.2009.01882.x

Wu, Q.S., Zou, Y.N., He, X.H. (2010). Contribution of arbuscular mycorrhizal fungi to growth, photosynthesis, root morphology and ionic balance of citrus seedlings under salt stress. Acta Plant Physiology, 32, 297-304. doi.10.1007/s11738-0090407-z

Zou, Y.N., Liang, Y.C., Wu, Q.S. (2013). Mycorrhizal and non-mycorrhizal responses to salt stress in trifoliate orange: plant growth, root architecture and soluble sugar accumulation. International Journal of Agriculture and Biology, 15, 565-569. 